\title{
The Operational Challenges of International Research Collaborations
}

\section{Sharon KLIM BN PGDACN(Emerg)}

Research Coordinator, Joseph Epstein Centre for Emergency Medicine Research @ Western Health, St Albans, Vic, Australia 3021

\section{Kerrie RUSSELL DipHIthSc(N) DipMgt AdvDipMgt(Community Sector)}

Administrative Officer, Office for Research Western Health and

Joseph Epstein Centre for Emergency Medicine Research @ Western Health, St Albans, Vic, Australia 3021

\section{Anne-Maree KELLY MD FACEM}

Corresponding author : Director, Joseph Epstein Centre for Emergency Medicine Research @ Western Health, St Albans Vic 3021 and Department of Medicine, Melbourne Medical School - Western Precinct, The University of Melbourne, St. Albans, Vic, Australia, 3021 Anne-Maree.Kelly@wh.org.au

Word count: 600

Tables: 1

This is the author manuscript accepted for publication and has undergone full peer review but has not been through the copyediting, typesetting, pagination and proofreading process, which may lead to differences between this version and the Version of Record. Please cite this article as doi: 10.1111/1742-6723.13435

This article is protected by copyright. All rights reserved. 
Collaborative networks for research are powerful. They facilitate faster collection of data and broader generalisability of findings. They also potentially allow smaller centres and less experienced researchers to participate in projects under the mentorship of the study centre. In structure, they may be formally constituted aiming to undertake multiple projects in a specialist field (e.g. Paediatric Research in Emergency Departments International Collaborative (PREDICT) [1]) or project-based and inclusive (e.g. Asia, Australia and New Zealand Dyspnoea in Emergency Medicine (AANZDEM).[2]

Recently the Joseph Epstein Centre for Emergency Medicine Research (JECEMR) has been the lead site for the HEAD (Headache in ED) study, a project-based international collaboration across Europe, the Middle East, South East Asia, Australia and New Zealand. The operational aspects of this project highlight the challenges of large, international research collaborations especially with respect to research governance and administrative processes.

JECEMR prefers to use inclusive, flexible networks rather than fixed ones because it promotes participation by smaller centres, harnesses enthusiasm and promotes mentoring of emerging researchers/centres. This approach however is not without its challenges. Approximately 100 sites, approached by email and social media, expressed interest in participation in the HEAD study - of which 74 eventually contributed data. JECEMR prepared and submitted all Australian Ethics Submissions (including those not covered by the National Mutual Acceptance (NMA) process). Although participating sites were responsible for submission of their Research Governance Application, JECEMR assisted most sites with the preparation and submission. Data was entered by local data collectors as de-identified data onto REDcap - a secure on-line platform. [3]

This article is protected by copyright. All rights reserved. 
The administrative and operational challenges summarised in Table 1 demonstrate the complexity of making a project like this happen and the resources needed. These should not be under-estimated when planning a project-based collaborative study in a flexible inclusive network. That said, the relationships built with participating sites and research offices are invaluable.

This article is protected by copyright. All rights reserved. 
Table 1: Operational and administrative challenges

\begin{tabular}{|c|c|}
\hline Process & Challenges \\
\hline \multirow[t]{4}{*}{ Researchers } & $\begin{array}{l}\text { Sensitively working with researchers to establish if they } \\
\text { realistically had capacity for the project. }\end{array}$ \\
\hline & Managing database access for 155 local researchers. \\
\hline & Achieving timely data entry. \\
\hline & $\begin{array}{l}\text { Nomination of a 'go-to' person for urgent actions, e.g. } \\
\text { signatures. }\end{array}$ \\
\hline \multirow[t]{2}{*}{$\begin{array}{l}\text { Australian Human Research } \\
\text { Ethics Committees (HREC) }\end{array}$} & $\begin{array}{l}\text { Despite national mutual acceptance processes, eight } \\
\text { separate applications were required to cover Australian } \\
\text { sites. }\end{array}$ \\
\hline & $\begin{array}{l}\text { Multiple HREC platforms are in use, all requiring different } \\
\text { processes and log-ins. }\end{array}$ \\
\hline \multirow[t]{2}{*}{$\begin{array}{l}\text { Research Governance } \\
\text { Office(RGO) }\end{array}$} & $\begin{array}{l}51 \text { separate research governance applications were } \\
\text { prepared for Australian sites. The governance submission } \\
\text { process changed at some sites whilst the application was } \\
\text { in progress. }\end{array}$ \\
\hline & $\begin{array}{l}\text { Some research Governance Organisations (RNG) would } \\
\text { not accept the waiver of consent approved by the } \\
\text { reviewing HREC, even though the HREC approval was via } \\
\text { the NMA process. }\end{array}$ \\
\hline
\end{tabular}

This article is protected by copyright. All rights reserved. 


\begin{tabular}{|l|l|}
\hline \multirow{y}{*}{} & $\begin{array}{l}\text { Some states had additional legislative requirements, e.g. } \\
\text { Public Health Act approval in Queensland and Data } \\
\text { Release request in Northern Territory. }\end{array}$ \\
\cline { 2 - 3 } & $\begin{array}{l}69 \text { collaborative research agreements/ memorandums of } \\
\text { understanding were negotiated. }\end{array}$ \\
\cline { 2 - 2 } & $\begin{array}{l}\text { JECEMR was required to apply to be an accredited } \\
\text { research organisation in Belgium. }\end{array}$ \\
\hline
\end{tabular}

\section{REFERENCES}

1. Babl F, Borland M, Ngo P, Acworth J, Krieser D, Pandit S et al. Paediatric Research in Emergency Departments International Collaborative (PREDICT): first steps towards development of an Australian and New Zealand Research Network. Emerg Med Australas. 2006 18:143-7.

2. Kelly AM, Keijzers G, Klim S, Graham CA, Craig S, Kuan WS et al. Asia, Australia and New Zealand Dyspnoea in Emergency Departments (AANZDEM) study: Rationale, design and analysis. Emerg Med Australas. 2015;27:187-91.

3. https://www.project-redcap.org/ Accessed 12 November 2019

This article is protected by copyright. All rights reserved. 


\section{University Library}

\section{- M M N E R VA A gateway to Melbourne's research publications}

Minerva Access is the Institutional Repository of The University of Melbourne

Author/s:

Klim, S;Russell, K;Kelly, A-M

Title:

Operational challenges of international research collaborations

Date:

2019-12-13

Citation:

Klim, S., Russell, K. \& Kelly, A. -M. (2019). Operational challenges of international research collaborations. EMERGENCY MEDICINE AUSTRALASIA, 32 (1), pp.172-+. https:// doi.org/10.1111/1742-6723.13435.

Persistent Link:

http://hdl.handle.net/11343/286739 